\title{
Anther specializations related to the division of labor in Microlicia cordata (Spreng.) Cham. (Melastomataceae)
}

\section{Mariana de Souza Carvalho Velloso ${ }^{*}$ (D), Vinícius Lourenço Garcia de Brito ${ }^{2}$, Ana Paula Souza Caetano ${ }^{3}$ (D) and Rosana Romero ${ }^{2}$ (1)}

Received: October 11, 2017

Accepted: January 31, 2018

\begin{abstract}
In heterantherous flowers, some anthers have an attraction and feeding function, while others are related to plant reproduction. Microlicia cordata has dimorphic stamens organized in two cycles: the antesepalous one with large stamens and pink anthers, and the antepetalous one with small stamens and yellow anthers. Division of labor was analyzed using the parameters of structure, composition, amount and estimated viability of pollen, and the color of floral parts. The anthers of the pollinating stamens were larger than the anthers of the feeding stamens, although anatomically similar. There was a difference in the amount of pollen produced by the anthers of the two cycles, but no difference was found in pollen viability. Considering a bee color vision model, the color of the anthers of the pollinating stamens contrasted less with that of the corolla, and thus is probably less attractive to visitors. Conversely, the anthers of the feeding stamens and the ventral appendage of the connective of the pollinating stamens contrasted more with the corolla, presenting the same color to the pollinators. These results are in accordance with the idea of division of labor among anthers of heterantherous flowers, especially regarding the quantity of pollen and the color of the floral parts.
\end{abstract}

Keywords: color vision, division of labor, heteranthery, Microlicia, pollen dilemma, poricidal anthers

\section{Introduction}

Among the Angiosperms, approximately 20,000 species contain pollen as the only reward for their pollinators in the so-called pollen flowers (Vogel 1978; Buchmann 1983; Luo et al. 2009). Among them, the buzz-pollinated flowers are adapted to pollination by bees and their pollen grains not only participate in the transport of male gametes, but are also consumed by these insects (Buchmann 1983; Vallejo-Marín et al. 2009). In this respect, the utilization of pollen for feeding potentially reduces the number of viable gametes for reproduction, leading to an evolutionary conflict known as the "pollen dilemma" (Westerkamp 1996; Luo et al. 2009; Vallejo-Marín et al. 2009; Lunau et al. 2014; Barônio et al. 2016).

The occurrence of two or more types of stamens in the same flower, or heteranthery, is understood as a mechanism for the solution of this conflict since it generates specialization of stamen types with different and specific functions in the pollination process (Luo et al. 2008; VallejoMarín et al. 2009; Barrett 2010). Usually, these stamens differ in shape, position, size and/or color, a condition that has arisen in at least 16 angiosperm families (Buchmann 1983; Luo et al. 2009; Vallejo-Marín et al. 2009; 2010; Barrett 2010). Such differences might also be associated

1 Programa de Pós-Graduação em Biologia Vegetal, Instituto de Biologia, Universidade Federal de Uberlândia, 38400-902, Uberlândia, MG, Brazil 2 Instituto de Biologia, Universidade Federal de Uberlândia, 38400-902, Uberlândia, MG, Brazil

3 Programa de Pós-Graduação em Ecologia e Conservação dos Recursos Naturais, Instituto de Biologia, Universidade Federal de Uberlândia, 38400-902, Uberlândia, MG, Brazil

* Corresponding author: marianadscarvalho@gmail.com 
with differences in the amount of pollen grains as well as pollen exine ornamentation and cytoplasmic content (Hrycan \& Davis 2005; Luo et al. 2009). Heteranthery was first described more than 150 years ago, when Darwin, in 1862 , stated that he was intrigueded by the phenomenon. A few years later, Müller (1881; 1882; 1883) suggested the division of labor between the different stamens, whereby one set would serve to feed and the other would act on the pollination process, as supported by current studies (Luo et al. 2008; 2009; Vallejo-Marín et al. 2009; Paulino et al. 2016; Papaj et al. 2017).

In Melastomataceae, heteranthery has been described in species of different tribes such as Bertolonieae, Melastomeae, Merianieae, Microlicieae, Rhexieae and Sonerileae (Müller 1881; Cogniaux 1891; Renner 1989; Mendoza \& Ramírez 2006; Luo et al. 2008). This family, although notoriously diverse, with more than 5.400 species (Goldenberg et al. 2015), typically possesses falciform anthers with poricidal dehiscence (Renner 1989; Santos et al. 2009). These characteristics cause pollen grains to be available only to bees that are able to vibrate their wing muscles during their visits to flowers, with pollen grains usually being the only reward offered by the flower (Renner 1989). Thus, the evolutionary history of the family is closely associated with a pollination system known as "buzz pollination" (Buchmann 1983; Renner 1989; Luo et al. 2008; Luca et al. 2013).

In species of this family, the androecium commonly consists of two stamen cycles (Cogniaux 1891; Mendoza \& Ramírez 2006; Luo et al. 2009). In the species with heteranthery, the set of "feeding" stamens (antepetalous) consists of smaller and more conspicuous elements and is located in an accessible place in the flower. In contrast, the remaining stamens (antesepalous), considered to be "pollinating" stamens, are larger, have a more discrete color or a color similar to that of the corolla and their location corresponds to the position of the stigma. This permits the pollen to be deposited in strategic places on the body of the bee that are not easily reached during the grooming behavior (Forbes 1882; Almeda 1977; Renner 1989; Luo et al. 2009; Ferreira \& Araújo 2016).

In addition to the morphology of the different types of stamens, the division of labor may be cryptic and involve the pollen grains from each type of anther, which may vary in structure, content, quantity and release dynamics (Mori et al. 1980; Nepi et al. 2003; Luo et al. 2008; Leite 2016; Paulino et al. 2016). Moreover, since heteranthery may be related to the color patterns of the floral parts, especially the corolla, stamens and ventral appendage of the connective (Fig. 1), it is essential to understand how the colors of these different structures are potentially perceived and discriminated by the pollinators, and if they also have some function in the process of division of labor (Luo et al. 2009; Ferreira \& Araújo 2016). Until now, the color patterns of such structures (i.e. conspicuous feeding anthers and cryptic pollinating anthers) were only considered in terms of humam-based color vision, but not in terms of bee color vision models. Once confirmed that the ventral appendage of the connective has the same color as the feeding anthers in the pollinator color vision, this structure would be considered a strategy increasing the attractiveness of the flowers, which would signal more stamens than the flower actually has (Dafni 1984; Lunau 2006). Within this context, the species of Microlicia (Melastomataceae) are good models for testing the division of labor between anthers at different levels, since they present two stamen cycles of different size, shape and color (Romero 2003), reflecting the extensive occurrence of heteranthery in the family.

The objective of the present study was to analyze the different levels of differentiation and speciallization of each type of anther in the flowers of Microlicia cordata and
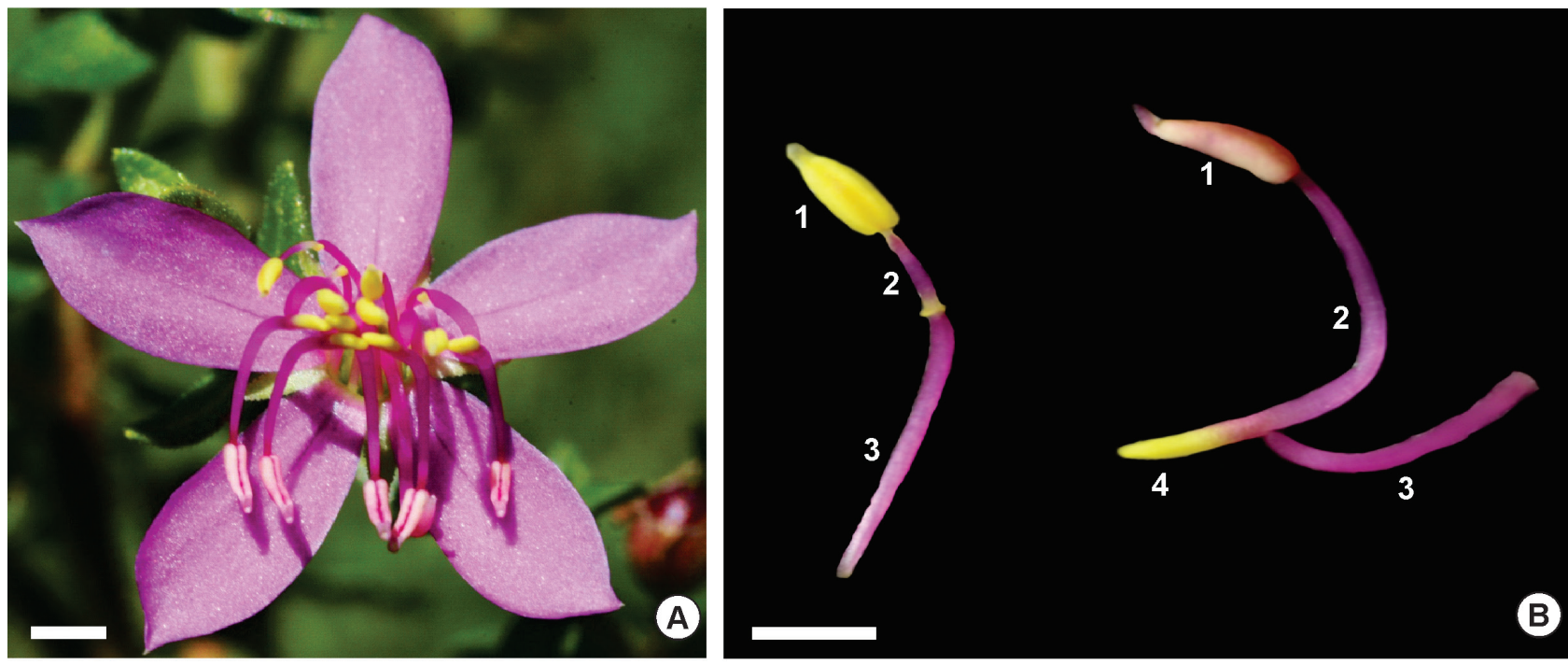

Figure 1. Microlicia cordata. A. Front view of a flower showing the presence of two morphological types of stamens; B. Detail of the morphology of the feeding stamen on the left, and of the pollinating stamen on the right. Symbols: 1: anther; 2: pedoconnective; 3: filament; 4: ventral connective appendage. Scale bars: A: $1.5 \mathrm{~mm}$; B: $1 \mathrm{~mm}$. 
to compare morphological and anatomical data between anthers and pollen grains from the pollinating and feeding stamens that may promote division of labor. The following questions were considered: 1) Are there differences in amount and viability of pollen grains, and in morphology and in cytoplasmic content between the feeding and pollinating anthers? 2) Are the anthers of the pollinating stamens less conspicuous than the anthers of the feeding stamens when compared to the corolla, considering bee color vision? 3) Do the anthers of the feeding stamens and the ventral appendage of the connective of the pollinating stamens have the same color? According to the division of labor hypothesis, we expect to find differences in pollen content and structure, as well as in pollen quantity and quality produced by different anthers. We also expect the pollination anthers to be more cryptic, whereas the feeding anthers and the ventral appendage of the connective of the pollinating stamens to be similar in color and more conspicuous to the pollinators.

\section{Materials and methods}

\section{Study area and species}

The study was conducted at the Private Natural Heritage Reserve (RPPN) of the Clube Caça e Pesca de Uberlândia, Minas Gerais, Brazil (18 $59^{\prime} \mathrm{S} 48^{\circ} 18^{\prime} \mathrm{W}$ ), an area of 640 hectares on the banks of the Uberabinha river covered with a cerrado sensu stricto, dry grasslands and palm swamp areas (Apolinário \& Schiavini 2002). The climate of the region is of the Aw type, with well-defined dry and rainy seasons (Alvares et al. 2013). The topography of the region is flat, the soil is acidic (latosol), dystrophic, permeable and sandy, mainly consisting of arenite and clay (Schiavini \& Araújo 1989). Individuals of Microlicia cordata (Spreng.) Cham. occur in sandy soil in the transition between palm swamp and cerrado sensu stricto (Bacci et al. 2016). Data were collected from April 2015 to December 2016.

Microlicia cordata is a much branched subshrub 40-90 $\mathrm{cm}$ tall, covered with hirsute and glandular sessile trichomes, with sessile leaves measuring 8-13 $\times 5-9 \mathrm{~mm}$. The flowers are hermaphroditic, solitary, pentamerous, with pedicels $1-3$ mm long; pink petals $4.5-6 \times 2-2.5 \mathrm{~mm}$, with an entire and glabrous margin, and have 10 dimorphic stamens arranged in the antesepalous and antepetalous cycles. Especially the antesepalous stamens have a long pedoconnective but both set of stamens have ovoid-oblong anthers with a slightly rostrate apex (Cogniaux 1883; Romero 2003; Bacci et al. 2016). A voucher of the species has been deposited at HUFU herbarium, Romero et al. 8688, HUFU 71013.

\section{Morphology and anatomy of the stamens and pollen grains}

Freshly opened flowers from 15 individuals were collected and photographed. The two stamen cycles were removed, numbered, and photographed in order to measure the size of the anthers, the pedoconnective and ventral appendage of the connective of both cycles, with the aid of ImageJ software (Hartig 2013). Structural measures were obtained from the photographs. Analysis of variance (ANOVA) was applied considering length as the response and structure (anther of the feeding stamen, anther of the pollinating stamen and ventral appendage of the connective of the pollinating stamen) as the independent variable. The lengths of the structures were then compared a posteriori by a pairwise t-test with Bonferroni corrections.

For the analysis of anatomy and pollen grain content, flower buds and freshy opened flowers of five M. cordata individuals were collected and fixed in $2 \%$ glutaraldehyde and $4 \%$ formaldehyde in $0.1 \mathrm{M}$ sodium phospate buffer, $\mathrm{pH}$ 6.8 (McDowell \& Trump 1976), dehydrated in an ethanol series and embedded in plastic resin (Gerrits \& Smid 1983). The material was cut into $2 \mu \mathrm{m}$ thick lengthwise and crosswise sections with a manual rotary microtome equipped with a disposable tungsten blade. The sections were stained with $0.05 \%$ Toluidine blue (O'Brien et al. 1964; Feder \& O'Brien 1968), or submitted to biochemical tests for the determination of the substances stored in the pollen grains. The Lugol reagent was used to detect starch (Johansen 1940), PAS was used to detect neutral polysaccharides (Feder \& O'Brien 1968), and Sudan IV and Sudan black (Pearse 1980) were used to detect total lipids. The material was observed and photographed with an Olympus BX51 microscope coupled to a DP70 digital camera. All analyses were performed in the Laboratory of Plant Morphology and Images of the Federal University of Uberlândia (LAMOVI - UFU).

\section{Amount and estimated viability of pollen grains}

The amount and estimated viability of pollen were determined for 90 pre-anthesis flowers collected from 30 individuals (three flowers per individual). The flower buds were fixed and stored in 50\% FAA (formaldehyde, glacial acetic acid, $50 \%$ ethanol; 5:5:90. v/v) (Johansen 1940). The anthers of the two stamen cycles were dissected separately in $100 \mu \mathrm{l}$ acetic carmine for the extraction of pollen grains. Next, $10 \mu \mathrm{l}$ of each sample were transferred to a hemocytometer and the number of pollen grains present in each quadrant of the chamber was quantified with the aid of an Olympus BX51 light microscope, and the total quantity of pollen per flower was estimated (Dafni et al. 2005). Pollen viability was estimated by staining the cytoplasm with $1.2 \%$ acetic carmine, and the counted grains were considered to be viable or not based on the presence or absence of cytoplasm staining (Radford et al. 1974).

A generalized linear mixed model was used for the comparison of the total quantity of pollen grains and for the estimate of pollen viability in each anther cycle, considering the anther type (anther of the feeding stamen or anther of 
the pollination stamen) as a fixed factor and the individual and the quadrant of the hemocytometer as random factors.

\section{Color of the floral parts}

The reflectance curves of the floral parts (corolla, anthers of the pollinating stamens and of the feeding stamens and ventral appendage of the connective of pollinating stamens) of 90 flowers in anthesis were collected from the same 30 individuals of the M. cordata population using an USB JAZ spectrophotometer (Ocean Optics, Inc.). A standard white (Ocean Optics, Inc.) and the absence of light as black were used for calibration. A color space model that takes into consideration the visual color ability of bees was later used to estimate the ability to discriminate the colors of these floral elements and of the corolla by potential bee pollinators (Chittka \& Menzel 1992; Lunau et al. 2011).

The color space model used was the color hexagon (Chittka 1992). A green leaf standard as background and a daylight illumination standard (D65, Wyszecki \& Stiles 1982) were used for the construction of the model. The spectral sensitivity curves for the three photoreceptors (UV, blue and green) of Apis mellifera were also used since this species is phylogenetically close to the genus Centris (Hedtke et al. 2013), bees that visit the flowers of M. cordata (VLG Brito, MSC Velloso unpubl. res.). In the color hexagon, the colors of the flower structures are represented as points occupying a locus and the distance between them reveals the difference between colors (Chittka \& Kevan 2005). To determine if the points of the floral parts occupy the same region of the color hexagon, the number of points representing each floral part was counted in each area of the hexagon and the data obtained were compared by a Chi-square test.

A null model was used to test the spatial overlap of the points that represent the anthers of the feeding stamens and of the ventral appendage of the connective of the pollinating stamen in the hexagon. In this model, the identity of the points was randomized 1000 times and the overlap of two sets of points was calculated for each randomization. To test whether the real overlap is greater than expected by chance, the real overlap was compared to the null distribution of the random overlaps considering a $95 \%$ confidence interval.

Since different colors may have the same preference by pollinators when they have the same chromatic contrast value (Lunau et al. 1996), these values were also compared for the anthers of the pollinating stamens, the anthers of the feeding stamens and the ventral appendages of the connective of the pollinating stamens in relation to the petal. The distance between loci was used as the measurement of color contrast and compared by analysis of variance (ANOVA), and then analyzed a posteriori by a Tukey test. All analyses were carried out using the R 3.0 (R 2016) statistical software and the "pavo" (Maia et al. 2013) and "lme4" (Bates et al. 2015) packages.

\section{Results}

\section{Morphology and anatomy of the stamens and pollen grains}

This species has an androecium with 10 dimorphic stamens organized in two cycles (Fig. 1A, B). The antesepalous (pollination) cycle consists of the five larger stamens, with pink anthers $1.48 \pm 0.04 \mathrm{~mm}$ long, strongly arched pink pedoconnectives $2.76 \pm 0.18 \mathrm{~mm}$, pink filaments $2.5 \pm 0.12$ $\mathrm{mm}$ long, and slightly bilobated yellow ventral appendages $1.02 \pm 0.06 \mathrm{~mm}$ long. The antepetalous (feeding) cycle contains the five smaller stamens, which have yellow anthers $1.23 \pm 0.03 \mathrm{~mm}$ long, pink pedoconnectives $0.79 \pm 0.05$ $\mathrm{mm}$ long, pink filaments $2.59 \pm 0.13 \mathrm{~mm}$ long, and yellow ventral appendages $0.16 \pm 0.01 \mathrm{~mm}$ long. The antesepalous stamens, antepetalous stamens and ventral appendage of the antesepalous stamens are of different sizes (ANOVA: $\mathrm{F}=98.4 ; \mathrm{df}=2 ; \mathrm{p}<0.001)$. The pollinating anthers are larger than the feeding anthers $(\mathrm{p}<0.001)$ and than the ventral appendage of the connective of the pollinating stamens ( $\mathrm{p}<0.001$ ), and, in turn, the feeding anthers are larger than the ventral appendage of the connective of the pollinating stamens $(\mathrm{p}<0.001)$.

The anthers of the two stamen cycles are anatomically similar, being bithecal and tetrasporangiate (Fig. 2A). At anthesis, the cells of the intersporangial septa are disintegrated, forming a single pollen sac or locule in each theca (Fig. 2B). Each anther is irrigated by a single vascular bundle, and in the stages observed, the anther wall is formed by epidermis and endothecium (Fig. 2A, B).

The pollen grains are released in monads at the bicellular stage formed by vegetative and generative cells (Fig. 2C-F). The vegetative cell is larger, occupies large part of the pollen grain and has a more or less centralized nucleus (Fig. 2C, E). The generative cell is considerably smaller, markedly elongated and fully located inside the cytoplasm of the vegetative cell (Fig. 2D, F). No polysaccharides or lipids were detected in pollen grains in any of the stages analyzed of the two cycles.

Several pollen grain abnormalities were detected in the anthers of the two stamen cycles, with some grains having little or no cytoplasmic content (Fig. 2G) and some containing two cells without morphological differentiation (Fig. 2H). The presence of immature stages such as vacuolated microspores was also observed in mature anthers (Fig. 2I).

\section{Amount and estimated viability of the pollen grains}

The anthers of the pollinating stamens produce more pollen grains than the anthers of the feeding stamens (Fig. $3 \mathrm{~A} ; \mathrm{Z}=-23 ; \mathrm{p}<0.001$ ). The mean number of pollen grains is $32.830 \pm 1.660$ in the anther of the pollinating stamen per flower and $17.430 \pm 920$ in the anther of the feeding stamen. On the other hand, there is no difference in the estimate of 

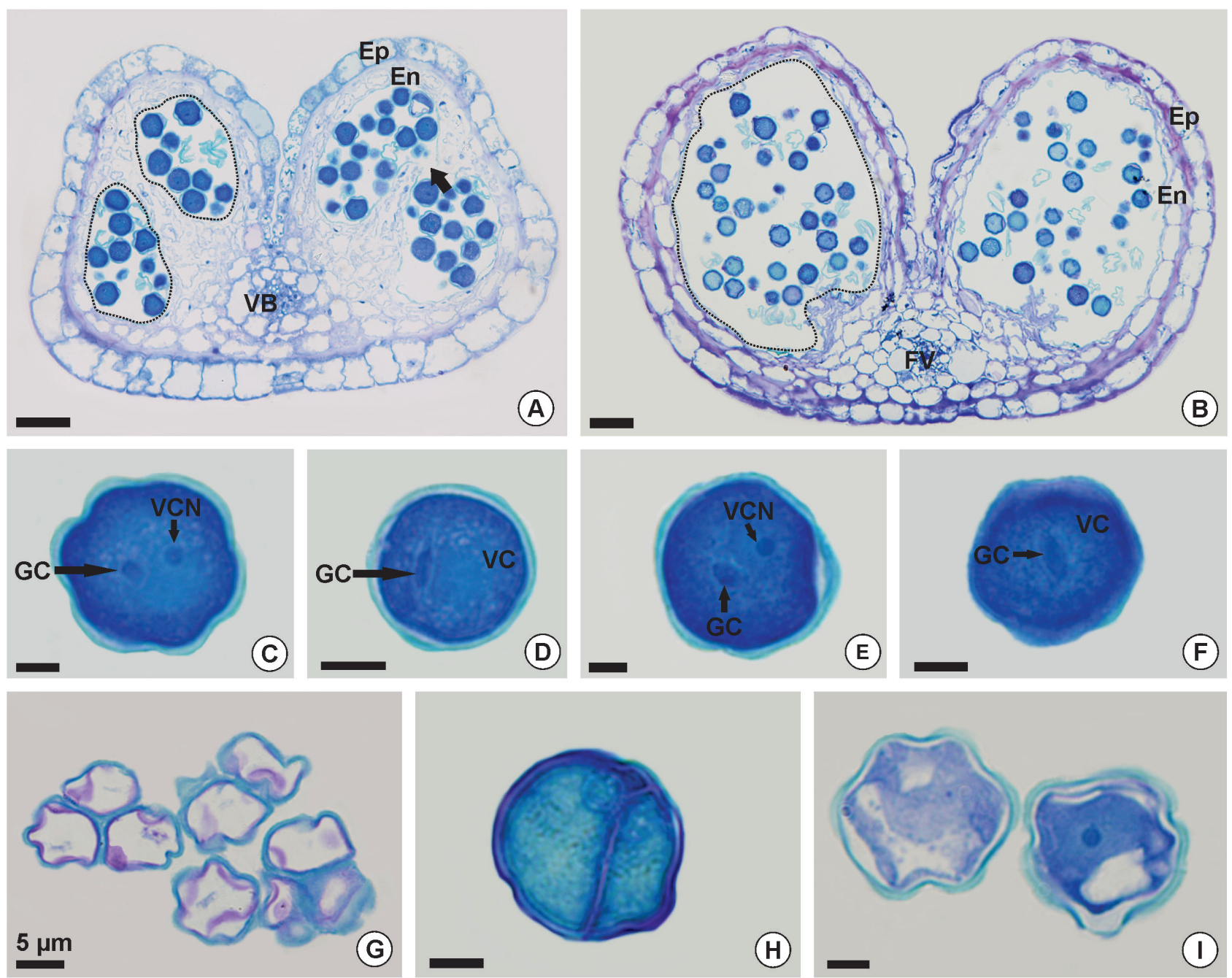

(H)

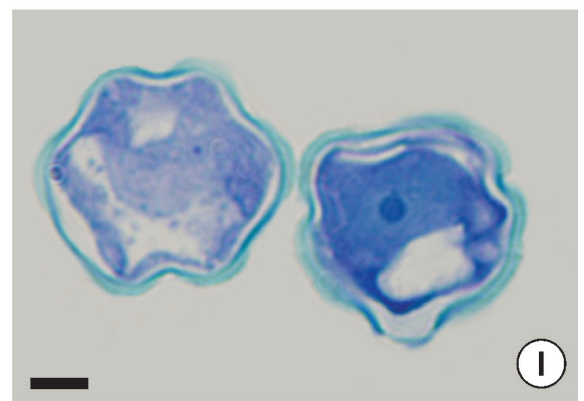

Figure 2. Anatomical aspects of the anther and of pollen grains of the feeding and pollinating stamens of Microlicia cordata. A. Transverse section of an anther of the feeding stamen showing the four sporangia and the beginning of degeneration of the intersporangial septum (arrow). The dotted circles delimit the two sporangia on one of the thecae; $\mathbf{B}$. Transverse section of an anther of the pollination stamen showing a single sporangium per theca due to the degeneration of the intersporangial septum. The dotted circle delimits the sporangia of one theca; C-D. Detail of mature pollen grains from the pollinating stamen; E-F. Detail of mature pollen grains from the feeding stamen; G. Pollen grains with little or no cytoplasmic content originating from the feeding stamen; H. Pollen grain with two morphologically identical cells originating from the pollinating stamen; I. Vacuolated microspores orignating from a feeding stamen. Abbreviations: En: endothecium; Ep: epidermis; GC: generative cell; VB: vascular bundle; VC: vegetative cell; VCN: vegetative cell nucleus. Scale bars: A: $20 \mu \mathrm{m}$; B: $25 \mu \mathrm{m}$; C-F: $2 \mu \mathrm{m}$; G: $5 \mu \mathrm{m}$; H-L: $2 \mu \mathrm{m}$.

pollen viability between anthers $(\mathrm{Z}=1.13 ; \mathrm{p}>0.05)$, with the anthers of the pollinating stamens having $50.89 \% \pm 2.80 \%$ viable pollen grains per flower and the anthers of the feeding stamens having $53.06 \% \pm 2.90 \%$ viable grains (Fig. 3B).

\section{Color of the floral parts}

The color of the anthers of the pollinating stamens is similar to that of the corolla, while the anthers of the feeding stamens and the ventral appendage of the connective of the pollinating stamens have a similar color. It is intersting to note that these two structures occupy the same region in the color hexagon and strongly contrast with the corolla. The reflectance curves indicated that the corolla and anther of the pollinating stamens have a greater reflectance in the blue and red ranges (Fig. 4A, B) corresponding to the pink/ purple color. On the other hand, the feeding stamens and the ventral appendage of the connective of the pollinating stamens show a high reflectance starting from $500 \mathrm{~nm}$ (Fig. 4C, D), which corresponds to the yellow and red range.

The floral parts occupy different regions of the hexagon $\left(\chi^{2}=17.8\right.$; d.f. $\left.=6 ; p<0.01\right)$. It was observed that $97 \%$ of the color points of the petal are located in the blue region and $80 \%$ of the color points of the anthers of the pollinating stamens are located in the blue-green region. In contrast, $99 \%$ of the points of the anthers of the feeding stamens and $83 \%$ of the points of the ventral appendage of the connective of the pollinating stamens occupy the same space 

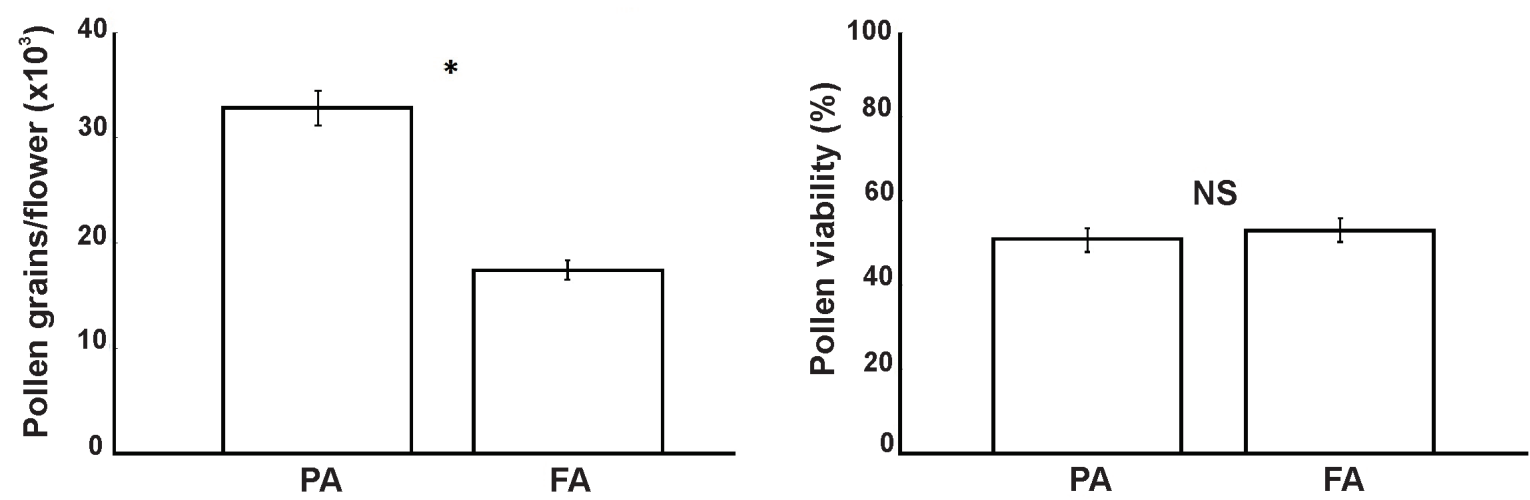

(A)

(B)

Figure 3. Number of pollen grains per flower $(\mathbf{A})$ and estimated pollen viability $(\mathbf{B})$ in the pollinating anthers $(\mathrm{PA})$ and feeding anthers (FA) of Microlicia cordata. (* significant in a $95 \%$ confidence interval. NS, nonsignificant).
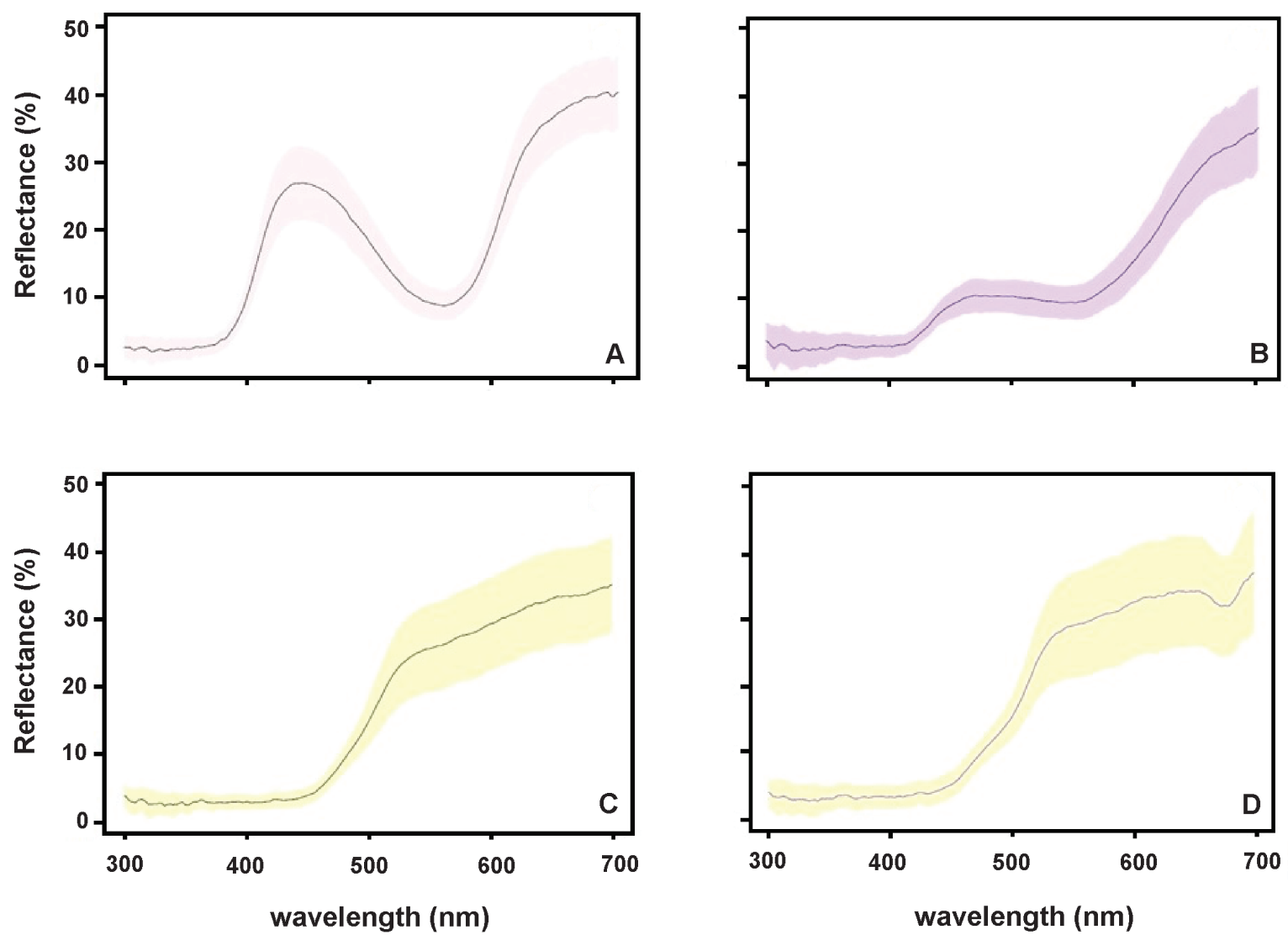

Figure 4. Reflectance curves of the floral parts of Microlicia cordata. A. Petal; B. Anther of the pollinating stamen; C. Anther of the feeding stamen; $\mathbf{D}$. Ventral appendage of connective of the pollinating stamen.

in the green region of the hexagon (Fig. 5). In addition, there is a $95.81 \%$ overlap between the points of the anthers of the feeding stamens and of the ventral appendage of the connective of the pollinating stamens in the color hexagon. This overlap was greater than expected by chance according to the null model $(\mathrm{p}<0.05)$, indicating that they have the same color in bee color vision.

The structures also differ in color contrast with the corolla $(F=25.19 ;$ d.f. $=2 ; p<0.001)$. Specifically, the contrast between the anther of the pollinating stamen and the corolla $(0.097 \pm 0.067)$ is lower than the contrast between the anther of the feeding stamen and the corolla $(0.151 \pm 0.312)$ $(t=-2.974 ;$ d.f. $=58 ; p<0.01)$. And the contrast between the anther of the pollinating stamen and the corolla is lower than the contrast between the ventral appendage of the connective of the pollinating stamen and the corolla (0.197 $\pm 0.311)(t=-6.069 ;$ d.f. $=58 ; p<0.001)$. However, there was no difference in color contrast between the anthers of the 


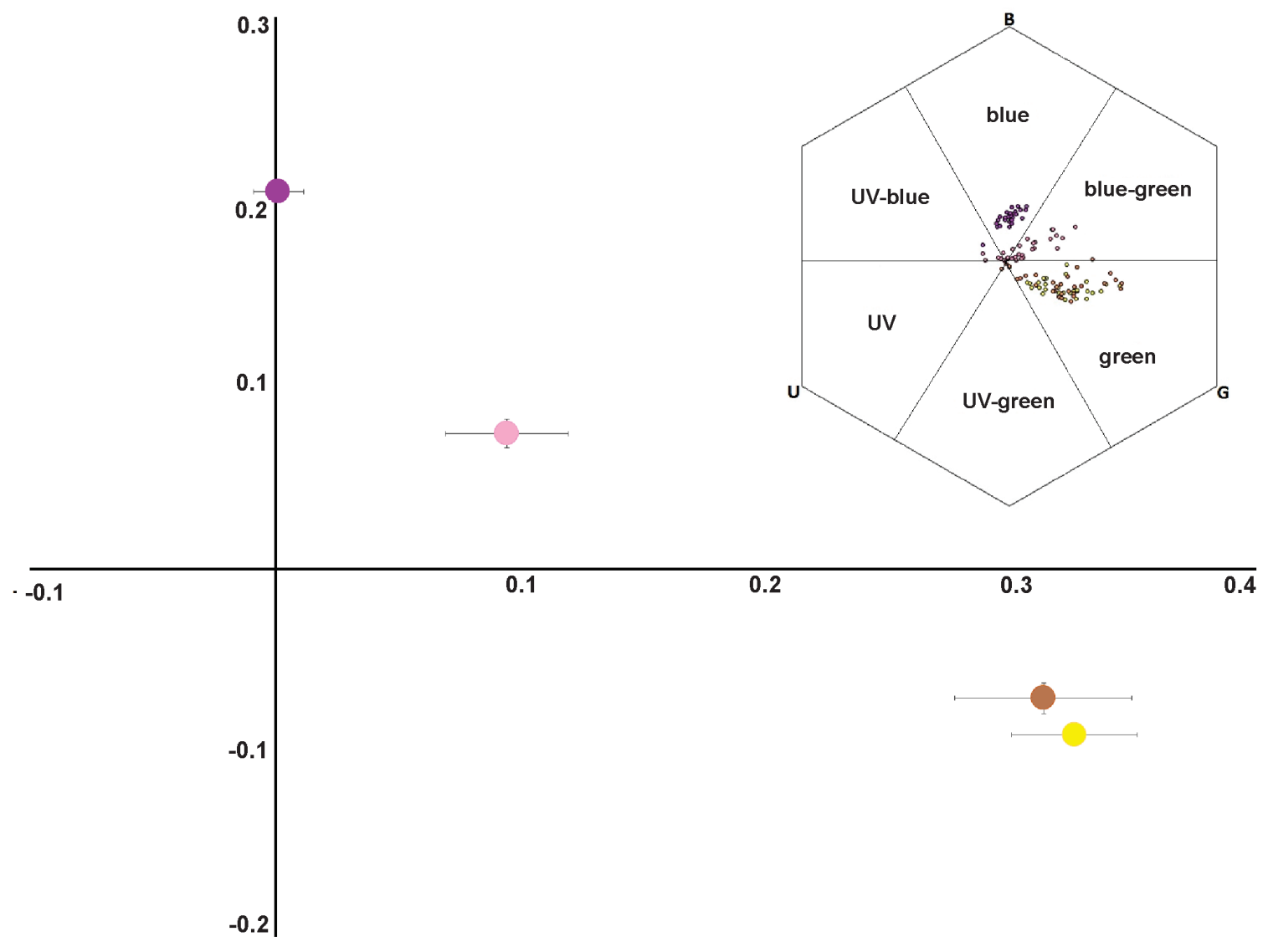

petal

pollinating anther

feeding anther ventral appendage of connective

Figure 5. Color space model for Apis (Hexagon). The points indicate where each floral part is located in the hexagon color model. The $\mathrm{x}$ - and y coordinates were calculated based on the values of stimulation of UV receptors, blue and green for each structure analyzed (Chittka 1992). Please see the PDF version for color reference.

feeding stamens or the ventral appendage of the connective of the pollinating stamens and the petals ( $t=-0.032$; d.f. $=58$; $\mathrm{p}=0.975)$.

\section{Discussion}

Microlicia cordata showed a clear dimorphism regarding the size, the amount of pollen grains and the color between the anthers of the feeding and pollinating stamens, especially when the color vision ability of bees is considered. However, the anatomical characteristics of the anthers or their structure and the viability of pollen grains do not differ between the stamen cycles of this species. Abnormalities were detected in the grains of both cycles.

Bithecal and tetrasporangiate anthers, endothecium without parietal fibrous thickenings and grains released in monads in the bicellular stage are conserved conditions frequently reported for Melastomataceae, regardless of the type of stamen (Tobe \& Raven 1983; Luo et al. 2008; Caetano et al. 2013a; b; Cortez et al. 2015). Particularly regarding the pollen grains, even though the parameters analyzed indicated great similarity of the grains from different types of anthers, some Melastomataceae species may differ in shape, size, pattern of wall ornamentation, viability and content of pollen grains of the feeding and pollination anthers (Forbes 1882; Luo et al. 2008; 2009). However, these differences do not involve all the species analyzed thus far (Almeda 1977; Fracasso \& Sazima 2004; Luo et al. 2009; Ferreira \& Araujo 2016; Soares \& Morellato 2018). The pollen grains from both cycles of the anthers of $M$. cordata are potentially functional in terms of participation in fertilization. On the other hand, the quantity of pollen grains is markedly greater in the larger pollinating anthers of $M$. cordata, as also observed in other Melastomataceae species (Müller 1881; Luo et al. 2008; 2009; Hoffmann \& Varassin 2011; Brito \& Sazima 2012; Ferreira \& Araújo 2016; Leite 2016) and in other angiosperm groups (Dulberger 1981; Paulino et al. 2016). This may be understood as a differential investment in the production of larger anthers 
and, consequently, more pollen grains that will be directly utilized in reproduction, a fact that can also be understood as a direct evolutionary response to the pollen dilemma (Luo et al. 2009; Valejo-Marín et al. 2009).

In addition, the different colors of the pollinating and feeding stamens of $M$. cordata are related to the role of each stamen type in the pollination process. The pink pollinating anthers have a discrete color that is less contrasting in relation to the corolla, suggesting that these anthers exert a low visual attraction on bees compared to the anthers of the feeding stamens (Müller 1881; Forbes 1882; Luo et al. 2008; 2009). Also, the pollinating stamens of M. cordata face the lower part of the flower, being located close to the stigma, while the feeding stamens are located in the central part of the flower, a common pattern in Melastomataceae species with heteranthery (Renner 1989; Gross \& Kukuk 2001; Fracasso \& Sazima 2004; Luo et al. 2008; Romero et al. 2015a; b; Romero \& Versiane 2016). This morphology permits deposition of the pollen from the pollinating and feeding anthers on different sites of the body of pollinators (Forbes 1882; Fracasso \& Sazima 2004; Luo et al. 2008; Vallejo-Marín et al. 2009; Ferreira \& Araújo 2016). In general, the pollinating anthers deposit more pollen grains on the dorsal surface of the bee's abdomen, a site of difficult access for grooming, while the feeding anthers deposit more pollen grains on the ventral surface of the abdomen, where access for feeding is facilitated (Luo et al. 2008; Kock et al. 2017).

On the other hand, the anthers of the feeding stamens function as an attraction for pollinators, especially due to their UV-absorbent yellow color that contrasts with that of the corolla (Lunau 2000; Heuschen et al. 2005), a pattern that seems to be common in the family. The color of the ventral appendage of the connective of the pollinating stamens is similar to that of these anthers since they occupy the same region in the color hexagon and produce the same contrast in relation to the corolla. Altough these central structures of the flower may also help and direct the pollinator during the flower visit, they do not guarantee that small bees will not have access to the pollination grains in some cases (Lunau 1992; Westerkamp 1996; Gross \& Kukuk 2001; Heuschen et al. 2005; Ferreira \& Araujo 2016). Thus, owing to its color and position, the ventral appendage of the connective of the pollinating stamens may play a major role as a signal for pollinator attraction in $M$. cordata.

The UV-absorbent yellow color of the anthers of the feeding stamens and of the ventral appendage of the connective of the pollinating stamens of $M$. cordata can be understood within the context of the hypothesis of "pollen and stamen mimicry", a common phenomenon in Angiosperms (Lunau et al. 2017; Lunau \& Wester 2017). According to this hypothesis, some plants exploit the innate preferences of their pollinators by being similar to the visual signals of the pollen grains when they reflect yellow absorbent UV, misleading the floral visitors that actively collect pollen (Lunau \& Wester 2017). Thus, this intrafloral mimicry system of $M$. cordata consists of three major components: 1) the model structure, as is the case for the anthers of the feeding stamens; 2) the mimicry structure, which is the ventral appendage of the pollinating stamens, and 3) the signal receptors, which are the visiting bees (Lunau 2006). Since the quantity of pollen is constant throughout floral anthesis, many species use these mimicry structures to overcome the disadvantages of attracting and rewarding floral visitors with all the pollen produced (Dafni 1984; Lunau 2006).

On this basis, three important intrafloral color processes occur in M. cordata, which mediate the interaction between flowers and pollinators. First, the anthers of the pollinating stamens are presented to the pollinators in a camouflaged manner due to their inconspicuous color compared to the corolla. Second, the anthers of the feeding stamens are quite attractive to the pollinators by having a color highly contrasting to that of the corolla and by honestly signaling the resource offered (pollen). Finally, the ventral appendage of the connective of pollinating stamens may be a mimicking structure because of the similarity of its color to that of the anthers of the feeding stamens. However, this color only mimics the anthers, increasing the attraction signal for the pollinators although no reward is directly offered by this structure. Such intrafloral process could be reinforced also by the scent characteristics of each strutucture, a hypothesis that should be addressed in future studies.

Supporting the hypothesis of the division of labor, the anthers of the pollinating stamens actually contain a larger amount of pollen grains compared to the anthers of the feeding stamens, possibly as a function of their larger size. However, there is no difference in pollen viability or in grain content, indicating that there is no pollen specialization related to the division of labor in the species under study. The color of the two stamen cycles permits us to conclude that they are related to the role of each flower part in the pollinating process, while the ventral appendage of the connective of pollinating stamens acts in a mimic manner, increasing the attraction signal for the pollinating agents. In this respect, we may extend the model of division of labor, commonly associated only with heteranthery, to other intrafloral attributes such as the quantity of pollen grains made available by each type of anther and its color pattern as perceived by pollinating bees.

\section{Acknowledgements}

We thank the Universidade Federal de Uberlândia (UFU) and the Programa de Pós-Graduação em Biologia Vegetal (PPGBV) for their infrastructure and support of the study, the Lababoratório de Morfologia, Microscopia e Imagem (LAMOVI), the "Clube Caça e Pesca Itororó de Uberlândia" (CCPIU) for permitting the study in the reserve area, and CAPES for the research fellowship granted in 2015 to the first author. The authors are also thankful for the financial suport offered by FAPEMIG (APQ-02497-16). 


\section{References}

Almeda F. 1977. Systematics of the neotropical genus Centradenia (Melastomataceae). Journal of the Arnold Arboretum 58: 73-108.

Alvares CA, Stape JL, Sentelhas PC, Gonçalves JLM, Sparovek G. 2013. Köppen's climate classification map for Brazil. Meteorologische Zeitschrift 22: 711-728.

Apolinário V, Schiavini I. 2002. Levantamento Fitossociológico de espécies arbóreas de Cerrado (stricto sensu) em Uberlândia - Minas Gerais. Boletim do Herbário Ezechias Paulo Heringer 10: 57-75.

Bacci LF, Versiane AFA, Oliveira ALF, Romero R. 2016. Melastomataceae na RPPN do Clube Caça e Pesca Itororó, Uberlândia, MG, Brasil. Hoehnea 43: 541-556.

Barônio GJ, Maciel AA, Oliveira AC, et al. 2016. Plantas, polinizadores e algumas articulações da biologia da polinização com a teoria ecológica. Rodriguésia 67: 1-19.

Barrett SCH. 2010. Darwin's legacy: the forms, function and sexual diversity of flowers. Philosophical Transactions of the Royal Society B 365: 351-368.

Bates D, Maechler M, Bolker B, Walker S. 2015. Fitting Linear MixedEffects Models Using lme4. Journal of Statistical Software 67: 1-48.

Brito VLG, Sazima M. 2012. Tibouchina pulchra (Melastomataceae): reproductive biology of a tree species at two sites of an elevational gradient in the Atlantic rainforest in Brazil. Plant Systematics and Evolution 298: 1271-1279.

Buchmann SL. 1983. Buzz pollination in Angiosperms. In: Jones CE, Little RJ. (eds.) Handbook of Experimental Pollination Biology. New York, Van Nostrand Reinhold. p. 73-113.

Caetano APS, Simão DG, Carmo-Oliveira R, Oliveira PE. 2013a. Diplospory and obligate apomixis in Miconia albicans (Miconieae, Melastomataceae) and an embryological comparison with its sexual congener $M$. chamissois. Plant Systematics and Evolution 299: 1253-1262.

Caetano APS, Teixeira SP, Forni-Martins ER, Carmello-Guerreiro SM. 2013b. Pollen insights into apomictic and sexual Miconia (Miconieae, Melastomataceae). International Journal of Plant Sciences 174: 760768.

Chittka L. 1992. The color hexagon: a chromaticity diagram based on photoreceptor excitations as a generalized representation of colour opponency. Journal of Comparative Physiology 170: 533-543.

Chittka L, Menzel R. 1992. The evolutionary adaptation of flower colours and the insect pollinators' colour vision. Journal of Comparative Physiology 171: 171-181.

Chittka L, Kevan PG. 2005. Flower colour as advertisement. In: Dafni A, Kevan PG, Husband BC. (eds.) Practical pollination biology. Cambridge, Enviroquest Ltd. p. 157-196.

Cogniaux CA. 1883. Microlicia. In: Martius CFP, Eichler AW, Urban I. (eds.) Flora Brasiliensis. Leipzig, Fleischer. p. 6-204.

Cogniaux CA. 1891. Melastomaceae. In: Candolle ALPP, Candolle CP. (eds.) Monographiae Phanerogamarum. Paris, Masson. p. 1-1256.

Cortez PA, Caetano APS, Carmello-Guerreiro SM, Teixeira SP. 2015. Anther wall and pollen development in Neotropical species-rich Miconia (Melastomataceae). Plant Systematics and Evolution 301: 217-230.

Dafni A. 1984. Mimicry and deception in pollination. Annual Review of Ecology and Systematics. 15: 259-278.

Dafni A, Kevan PG, Husband BC. 2005. Practical pollination ecology. Cambridge, Enviroquest Ltd.

Darwin C. 1862. Carta a Asa Gray, 22 de janeiro. http://www.darwinproject. ac.uk/letter/DCP-LETT-3404.xml. 10 Dec. 2016

Dulberger R. 1981. Dimorphic exine sculpturing in three distylous species of Linum (Linaceae). Plant Systematics and Evolution 139: 113-119.

Feder N, O’Brien TP. 1968. Plant microtechnique: some principles and new methods. American Journal of Botany 55: 123-142.

Ferreira QIX, Araújo FP. 2016. Economia de pólen favorecida pela heteranteria em Desmocelis villosa (Melastomataceae). Rodriguésia 67: 347-355

Forbes HO. 1882. Two kinds of stamen with different functions in the same flower. Nature 26: 386.
Fracasso CM, Sazima M. 2004. Polinização de Cambessedesia hilariana (Kunth) DC. (Melastomataceae): sucesso reprodutivo versus diversidade, comportamento e frequência de visitas de abelhas. Revista Brasileira de Botânica 27: 797-804.

Gerrits PO, Smid L. 1983. A new, less toxic polymerization system for the embedding of soft tissues in glycol methacrylate and subsequent preparing of serial sections. Journal of Microscopy 132: 81-85.

Goldenberg R, Almeda F, Sosa K, Ribeiro RC, Michelangeli FA. 2015. Rupestrea: A new Brazilian genus of Melastomataceae, with anomalous seeds and dry indehiscent fruits. Systematic Botany 40: 561-571.

Gross CL, Kukuk PF. 2001. Foraging strategies of Amegilla anomala at the flowers of Melastoma affine - no evidence for separate feeding and pollinating anthers. Acta Horticulturae 561: 171-178.

Hartig SM. 2013. Basic Image Analysis and Manipulation in ImageJ. Current Protocols in Molecular Biology 102: 14.15.1-14.15.12.

Hedtke SM, Patiny S, Danforth BN. 2013. The bee tree of life: a supermatrix approach to avoid phylogeny and biogeography. BMC Evolutionary Biology 13:138.

Heuschen B, Gumbert A, Lunau K. 2005. A generalised mimicry system involving angiosperm flower colour, pollen and bumblebees' innate colour preferences. Plant Systematics and Evolution 252: 121-137.

Hoffmann GM, Varassin IG. 2011. Variação da viabilidade polínica em Tibouchina (Melastomataceae). Rodriguésia 62: 223-228.

Hrycan WC, Davis AR. 2005. Comparative structure and pollen production of the stamens and pollinator-deceptive staminodes of Commelina coelestis and C. dianthifolia (Commelinaceae). Annals of Botany 95: 1113-1130.

Johansen DA. 1940. Plant microtechnique. New York, McGraw-Hill Book Company Inc.

Kock L, Lunau K, Wester P. 2017. To be on the safe site - Ungroomed spots on the bee's body and their importance for pollination. PlosONE 12: e0182522. doi: 10.1371/journal.pone.0182522

Leite FB. 2016. Função da heteranteria em duas espécies de Tibouchina (Melastomataceae): atração de abelhas e dinâmica de pólen. MSc Thesis, Universidade Estadual de Campinas, Campinas.

Luca PA, Bussiere LF, Souto-Vilaros D, Goulson D, Mason AC, VallejoMarin M. 2013. Variability in bumblebee pollination buzzes affects the quantity of pollen released from flowers. Oecologia 172: 805-816.

Lunau K. 1992. A new interpretation of flower guide coloration - Absorption of ultraviolet-light enhances colour saturation. Plant Systematics and Evolution 183: 51-65.

Lunau K. 2000. The ecology and evolution of visual pollen signals. Plant Systematics and Evolution 222: 89-111.

Lunau K. 2006. Stamens and mimic stamens as components of floral colour patterns. Botanische Jahrbücher 127: 13-41.

Lunau K, Konzmann S, Winter L, Kamphausen V, Ren Z. 2017. Pollen and stamen mimicry: the alpine flora as a case study. Arthropod-Plant Interactions 11: 427-447.

Lunau K, Papiorek S, Eltz T, Sazima M. 2011. Avoidance of achromatic colours by bees provides a private niche for hummingbirds. Journal of Experimental Biology 214: 1607-1612.

Lunau K, Piorek V, Krohn O, Pacini E. 2014. Just spines-mechanical defense of malvaceous pollen against collection by corbiculate bees. Apidologie 46: 144-149.

Lunau K, Wacht S, Chittka L. 1996. Colour choices of naive bumble bees and their implications for colour perception. Journal of Comparative Physiology A: Neuroethology, Sensory, Neural, and Behavioral Physiology 178: 477-489.

Lunau K, Wester P. 2017. Mimicry and deception in pollination. In: Becard G. (ed.) How plants communicate with their biotic environment. Amsterdam, Academic Press. p. 259-279.

Luo Z, Zhang D, Renner SS. 2008. Why two kinds of stamens in buzzpollinated flowers? Experimental support for Darwin's division-oflabour hypothesis. Functional Ecology 22: 794-800.

Luo Z, Gu L, Zhang D. 2009. Intrafloral differentiation of stamens in heterantherous flowers. Journal of Systematics and Evolution 47 : 43-56.

Maia R, Eliason CM, Bitton PP, Doucet SM, Shawkey MD. 2013. Pavo: an $R$ package for the analysis, visualization and organization of spectral data. Methods in Ecology and Evolution 4: 906-913. 
McDowell EM, Trump BF. 1976. Histologic fixatives suitable for diagnostic light and electron microscopy. Archieves of Pathology \& Laboratory Medicine 100: 405-414.

Mendoza H, Ramírez B. 2006. Guía ilustrada de géneros de Melastomataceae y Memecylaceae de Colombia. Bogotá, Instituto de Investigación de Recursos Biológicos Alexander von Humboldt, Univerisad del Cauca.

Mori SA, Orchard JE. 1980. Intrafloral Pollen Differentiation in the New World Lecythidaceae, Subfamily Lecythidoideae. Science 209: 400-403.

Müller H. 1881. Two kinds of stamens with different functions in the same flower. Nature 24: 307-308.

Müller H. 1882. Two kinds of stamens with different functions in the same flower. Nature 26: 386 .

Müller H. 1883. Two kinds of stamens with different functions in the same flower. Nature 27: 364-365.

Nepi M, Guarnieri M, Pacini E. 2003. Real and feed pollen of Lagerstroemia indica: Ecophysiological differences. Plant Biology 5: 311-314.

O’Brien TP, Feder N, Mccully ME. 1964. Polychromatic staining of plant cell walls by Toluidine Blue O. Protoplasma 59: 368-373.

Papaj DR, Buchmann SL, Russell AL. 2017. Division of labour of anthers in heterantherous plants: flexibility of bee pollen collection behavior may serve to keep plants honest. Arthropod-Plant Interactions 11: 307-315.

Paulino JV, Mansano VF, Prenner G. 2016. Evidence for division of labor and division of function related to the pollen release in Papilionoideae (Leguminosae) with a heteromorphic androecium. International Journal of Botany 177: 590-607.

Pearse AGE. 1980. Histochemistry theoretical and applied: preparative and optical technology. 4th. edn. London/ Edinburgh, Churchill Livingston.

Radford AE, Dickison WC, Massey JR, Bell CR. 1974. Vascular plant systematics. New York, Harper \& Row.

Renner SS. 1989. A survey of reproductive biology in Neotropical Melastomataceae and Memecylaceae. Annals of the Missouri Botanical Garden 76: 496-518.

Romero R. 2003. Revisão taxonômica de Microlicia sect. Chaetostomoides (Melastomataceae). Revista Brasileira de Botânica 26: 429-435.
Romero R, Silva KR, Simão DG. 2015a. Microlicia cogniauxiana and Microlicia naudiniana (Melastomataceae), two new species from the Espinhaço range, Brazil. Systematic Botany 40: 1012-1021.

Romero R, Silva KR, Simão DG. 2015b. Microlicia crassa and M. maculata ssp. nov. (Melastomataceae) from Minas Gerais, Brazil: morphology and leaf anatomy. Nordic Journal of Botany 33: 178-185.

Romero R, Versiane AFA. 2016. Microlicia candolleana (Melastomataceae): a new endemic species to the Espinhaço range, Minas Gerais, Brazil. Phytotaxa 261: 275-281.

Santos AKA, Martins AB, Romero R. 2009. Melastomataceae. In: Giulietti AM, Rapini A, Andrade MJG, Queiroz LP, Silva JMC. (eds.) Plantas raras do Brasil. Belo Horizonte, Conservação Internacional, Universidade Estadual de Feira de Santana. p. 263-279.

Schiavini I, Araújo GM. 1989. Considerações sobre a vegetação da Reserva ecológica do Panga (Uberlândia). Sociedade \& Natureza 1: 61-66.

Soares NC, Morellato LPC. 2018. Crepuscular pollination and reproductive ecology of Trembleya laniflora (Melastomataceae), an endemic species in mountain rupestrian grasslands. Flora 238: 138-147.

Tobe H, Raven PH. 1983. An embryological analysis of Myrtales: its definition characteristics. Annals of the Missouri Botanical Garden 70: 71-94.

Vallejo-Marín M, Manson JS, Thomson JD, Barrett SCH. 2009. Division of labour within flowers: heteranthery, a floral strategy to reconcile contrasting pollen fates. Journal of Evolutionary Biology 22: 828-839.

Vallejo-Marín M, Silva EM, Sargent RD, Barrett SCH. 2010. Trait correlates and functional significance of heteranthery in flowering plants. New Phytologist 188: 418-425.

Vogel S. 1978. Evolutionary shifts from reward to deception in pollen flowers. In: Richards AJ. (ed.) The pollination of flowers by insects. London, Academic Press. p. 89-96.

Westerkamp C. 1996. Pollen in bee-flower relations: some considerations on melittophily. Botanica Acta 109: 325-332.

Wyszecki G, Stiles WS. 1982. Color science: Concepts and methods, quantitative data and formulae. 2nd. NewYork, Wiley. 